\title{
CPU USAGE DARI PENGGUNAAN CLOUD GAMINGANYWHERE PADA GAME DENGAN SPEECH RECOGNITION SYSTEM SEBAGAI COMMAND INPUT
}

\author{
Sussi $^{1}$, Rendy Munadi ${ }^{2}$, Nurwulan Fitriyanti ${ }^{3}$, Indra Perdana Putra Sutejo ${ }^{4}$ \\ 1,2,3,4,Fakultas Teknik Elektro, Universitas Telkom, Bandung, Indonesia \\ 1sussiss@telkomuniversity.ac.id, ${ }^{2}$ rendymunadi@telkomuniversity.ac.id, \\ ${ }^{3}$ nurwulanf@telkomuniversity.ac.id, ${ }^{4}$ indraperdanaps@ student.telkomuniversity.ac.id
}

\begin{abstract}
Abstrak
Perkembangan game yang semakin maju menuntut pemain untuk memiliki perangkat dengan spesifikasi yang lebih tinggi. Game dengan gameplay yang kompleks tidak memungkinkan untuk dijalankan pada perangkat yang memiliki spesifikasi rendah. Teknologi cloud gaming membuat pemain dapat menjalankan game berspesifikasi tinggi diperangkat yang berspesifikasi rendah. Penelitian ini juga menggunakan teknologi speech recognition system dalam kendali input ketika memainkan game sehingga pemain yang memiliki keterbatasan motoris tangan tetap dapat menjalankan game. Cloud gaming yang digunakan pada penelitian adalah model GamingAnywhere. Metode penelitian yang digunakan yaitu dengan mengukur tingkat penggunaan CPU pada server, dan dua buah client ketika saling terhubung dengan GamingAnywhere. Dari hasil pengukuran, dapat dilihat bahwa server hanya membutuhkan 10-12\% CPU usage untuk memainkan game NEVERBALL dan 43-71\% CPU usage untuk memainkan game 7 Days to Die. Client hanya membutuhkan 34-58\% CPU usage untuk memainkan game NEVERBALL dan 22-25\% CPU usage untuk memainkan game 7 Days to Die.
\end{abstract}

Kata Kunci: CPU Usage, Cloud Gaming, GamingAnywhere

\section{Abstract}

The rapid development in game making demands users to posses the device with higher specifications. Games with more complex gameplay are not possibly run on the device with lower specifications. Cloud Gaming technology makes it possible for users to run games with higher specifications on the device with lower specifications. Researchers in the study have used speech recognition system technology to be used as control input when playing the game as it eases users with motoric disabilities to keep playing the game.

Cloud Gaming service used in this study is GamingAnywhere model. The method used to research this is study is by measuring CPU usage on the server, a client, and two clients when connected to GamingAnywhere service. The result is that the server only needs $10-12 \%$ of CPU usage to play NEVERBALL game and $43-71 \%$ of CPU usage to play 7 Days to Die game. From the client-side, CPU usage needed to play NEVERBALL is 34-58\% and 22-25\% CPU usage to play 7 Days to Die.

Key Words: CPU Usage, Cloud Gaming, GamingAnywhere

\section{Pendahuluan}

Game sudah menjadi salah satu sarana hiburan bagi masyarakat di berbagai belahan dunia pada saat ini. Industri gaming telah masuk menuju fase Next Generation Gaming dimana kualitas game secara kesuluruhan sangat baik diantaranya dari segi grafis dengan tingkat realisme yang tinggi dan pemakaian efek partikel yang kompleks. Dampak dari kemajuan indutri gaming yaitu kebutuhan akan perangkat komputer dengan spesifikasi yang sangat tinggi untuk menjalankan game [1] [2].

Sebagian besar game dimainkan dengan pengendali manual seperti tetikus dan keyboard dimana, orang normal tidak menjadi masalah dalam penggunaannya. Beberapa orang dengan kerusakan motorik (motor impairment) tidak bisa menggunakan pengendali manual secara efektif sehingga tidak dapat merasakan keuntungan dari game yang dimainkan [3].

Penelitian Cloud Gaming dengan Speech
Recognition System sebagai pengendali game memungkinkan game komputer menjadi lebih mudah diakses oleh semua kalangan. Hands-free access akan membantu orang dengan kerusakan motorik untuk dapat memainkan game [3]. Cloud gaming akan membuat 
game dapat dimainkan walaupun pada perangkat komputer yang low-end.

Salah satu bentuk dari hands-free access adalah masukan pengendali game melalui suara (speech input). Sistem pengenalan suara tidak memerlukan perangkat keras yang rumit dan mahal dibandingkan eye-tracker atau head-tracker. Selain itu, bahasa manusia memungkinkan jumlah kata yang tak terbatas untuk diucapkan dan sangat berguna untuk melakukan kendali dalam beberapa game yang membutuhkan kombinasi keystroke untuk dieksekusi [4].

Tujuan penelitian yaitu mengimplementasikan speech recognition system pada dua buah game agar dapat dikendalikan dengan menggunakan perintah suara, memainkan game berspesifikasi tinggi dengan perangkat komputer low-end melalui cloud GamingAnywhere dan melakukan analisis resource usage.

\section{Dasar Teori dan Perancangan}

\subsection{Cloud Computing}

Cloud Computing adalah suatu layanan teknologi informasi yang dapat dimanfaatkan oleh pengguna berbasis jaringan. Menurut NIST, cloud computing adalah sebuah model akses jaringan on-demand untuk menyatukan pengaturan konfigurasi sumber daya komputasi (jaringan, server, media penyimpanan, aplikasi, layanan) yang cepat ditetapkan dan dirilis dengan usaha manajemen yang minimal atau interaksi dengan penyedia layanan [5] [3]. Gambar 1 menunjukan perangkat cloud computing.

Cloud Computing mempunyai dua kata yaitu Cloud dan Computing. Cloud berarti awan atau internet dan computing yaitu proses komputasi. Konsep cloud computing sebagai internet (awan besar) yang berisi sekumpulan komputer yang saling terhubung.

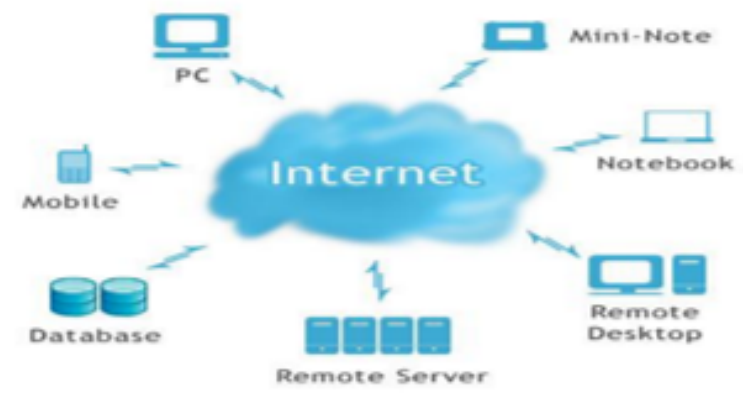

Gambar 1. Cloud Computing [5]

\subsection{Cloud Gaming}

Cloud gaming menghasilkan sebuah aplikasi gaming interaktif secara remote di dalam cloud dan meneruskan output berupa video ke pemain melalui internet [2]. Could gaming dibagi ke dalam tiga kategori: (a) 3D streaming grafis, (b) streaming video, dan (c) streaming video dengan operasi pasca-rendering . Ketiga kategori cloud gaming berbeda satu sama lain dalam cara membagi beban kerja antara server dan klien.

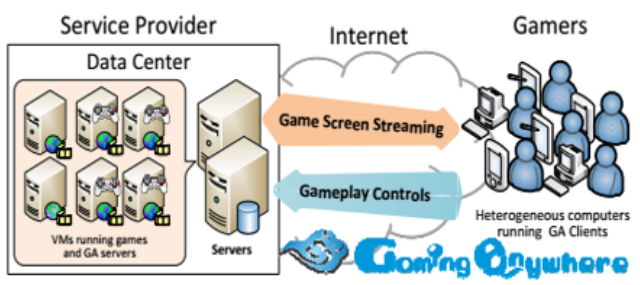

\section{Gambar 2. Layanan cloud gaming berdasarkan GamingAnywhere}

Gambar 2 menunjukkan layanan cloud gaming, di mana server game streaming mengirim permainan ke thin client dan thin client mengirim gameplay kontrol (penekanan tombol, gerakan mouse) kembali ke server game. Dengan cloud gaming, gamer dapat memainkan game komputer terbaru di mana saja dan kapan saja [6].

\subsection{Gaming Anywhere}

Gaming Anywhere merupakan salah satu platform cloud gaming yang bersifat open source dan cross platform. Game yang dijalankan pada perangkat komputer dapat dimainkan melalui perangkat lainnya seperti smartphone.

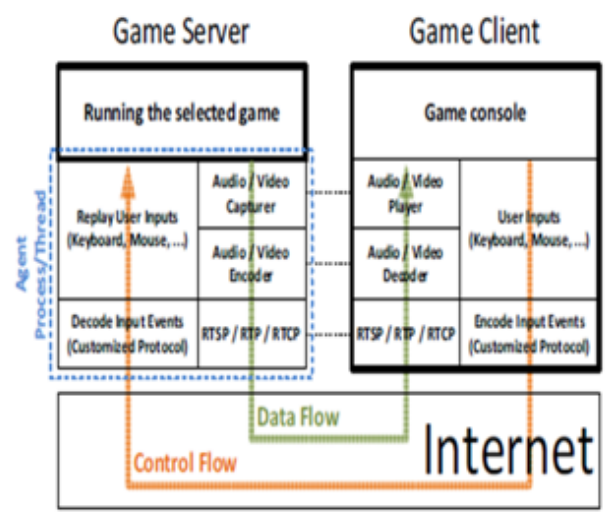

Gambar 3. Sistem Kerja GamingAnywhere [7]

Terdapat dua jenis network flow pada arsitektur GamingAnywhere yakni data flow dan control flow. Data flow digunakan untuk menstreamkan frames audio dan video dari server ke client sedangkan control flow berjalan dalam arah yang berlawanan untuk mengirimkan gerakan gamer dari sisi client ke server.

GamingAnywhere memiliki tiga keunggulan utama dibandingkan sistem lain yang ada yaitu :

1. GamingAnywhere adalah sistem terbuka (open system) dimana komponen dari streaming video 
dapat digantikan oleh komponen lain yang mengimplementasikan algoritma atau standar yang berbeda protokol.

2. GamingAnywhere adalah cross-platform dan tersedia di Windows, Linux, OS X dan Android.

3. GamingAnywhere dirancang menjadi lebih efisien dalam meminimalkannya waktu dan ruang overhead dengan menggunakan buffer sirkular bersama untuk mengurangi jumlah salinan memori operasi [2].

\subsection{Virtual Machine}

Virtual machine adalah perangkat lunak komputer yang berfungsi seperti komputer fisik dimana dapat menjalankan sistem operasi dan aplikasi. Virtual machine tersusun dari sekumpulan berkas konfigurasi dan spesifikasi yang didukung oleh physical resources milik host [8].

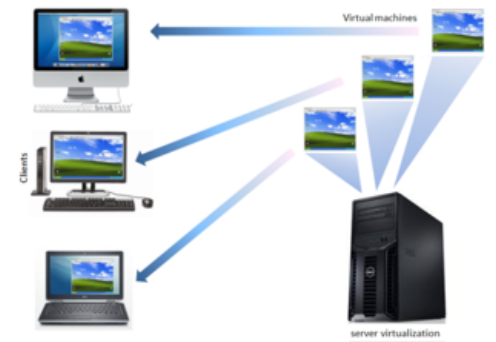

Gambar 4. Virtual Machine [8]

\subsection{Server}

Server adalah sebuah program yang menerima dan merespon permintaan yang dibuat oleh program lainnya (client) [9]. Setiap perangkat (laptop, PC) yang menjalankan piranti lunak server dapat dianggap sebuah server [9]. Server digunakan untuk mengatur sumber daya jaringan. Pengguna dapat mendirikan sebuah server untuk akses kontrol ke sebuah jaringan, mengirimkan, menerima email atau meng-host sebuah situs web.

\section{Game Server}

Game Server adalah server lokal yang dikontrol secara remote oleh client untuk online game [4].

\section{Game Client}

Game Client adalah program piranti lunak yang menghubungkan client ke game server. Server menyediakan koneksi dan mengirimkan paket-paket informasi ke client. Beberapa client dapat terkoneksi dengan server secara bersamaan. Masing-masing client memiliki perspektif atau tampilan game yang berbeda-beda.

\subsection{Speech Recognition System}

Speech recognition system adalah proses konversi suara menjadi sebuah teks (speech-to-text). Speech recognition memungkinkan gamer memberikan perintah atau masukan (input) kepada aplikasi tertentu dengan menggunakan suara. Proses speech recognition dilakukan oleh sebuah komponen piranti lunak yang disebut speech recognition engine [7].

Speech recognition engine dapat mengerjakan salah satu dari dua hal, yaitu :

1. Menerjemahkan hasil dari recognition sebagai sebuah perintah dan bertindak sebagai sebuah command and control.

2. Menangani teks yang dikenali (recognized text) hanya sebagai teks saja, maka Speech recognition engine bertindak sebagai aplikasi dikte (dictation).

\subsection{NEVERBALL}

NEVERBALL adalah salah satu free game dengan genre physics ball-rolling game, di mana pemain akan menggoyangkan lantai untuk menggerakkan sebuah bola sampai mencapai tujuan. NEVERBALL dapat dimainkan pada operasi sistem Linux, Windows, FreeBSD dan Mac OSX.

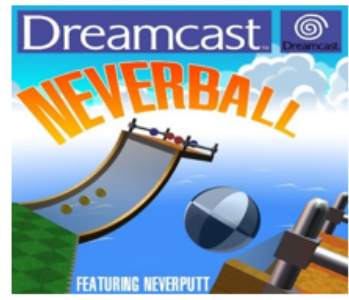

Gambar 5. Cover game NEVERBALL

\subsection{Days to Die}

7 Days to Die merupakan sebuah game yang dirilis pada tanggal 14 Desember 2013 dengan genre open-world survival horror yang dikembangkan oleh The Fun Pimps. Gamer akan memainkan karakter seorang manusia dan berusaha untuk bertahan hidup selama mungkin dari serangan zombie. Game 7 Days to Die disetting seperti dunia post-apocalyptic yang dipenuhi oleh mayat hidup.

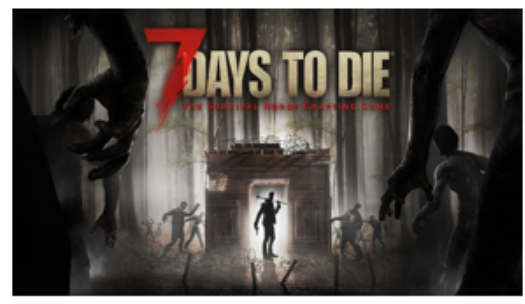

Gambar 6. Cover game 7 Days to Die 


\section{Metode Pengukuran}

Diagram alir secara keseluruhan dari penggunaan cloud GamingAnywhere yang dikendalikan oleh masukan suara ditunjukkan pada Gambar 7. Input suara akan diolah menggunakan platform FreeePIE. Skenario pengukuran parameter akan dilakukan ketika client terhubung dengan server dan sesi gaming berlangsung.

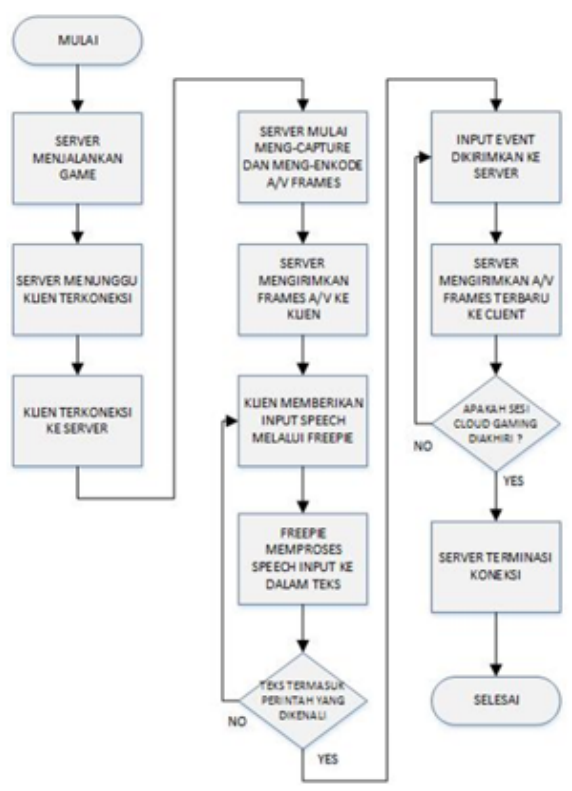

Gambar 7. Diagram alir model penelitian secara keseluruhan

\subsection{Spesifikasi Game Uji}

Penelitian dengan menggunakan platform cloud gamingAnywhere beserta inputan suara sebagai pengendali game membutuhkan dua buah game dan dua buah PC dengan spesifikasi berikut:

\section{NEVERBALL}

Tabel 1. System requirement game NEVERBALL

\begin{tabular}{|l|l|}
\hline Processor & $500 \mathrm{MHz}$ Processor \\
\hline Graphics & OpenGL 1.2.1 or greater \\
\hline Memory & $128 \mathrm{MB}$ \\
\hline Storage & $200 \mathrm{MB}$ \\
\hline
\end{tabular}

\section{7 Days to Die}

Tabel 2. System requirement game 7 Days to Die

\begin{tabular}{|l|l|}
\hline OS & Windows XP (SP3) \\
\hline Processor & 2.4 Ghz Dual Core \\
\hline Graphics & 512 MB dedicated memory \\
\hline Memory & 4GB RAM \\
\hline Storage & 3GB \\
\hline
\end{tabular}

3. PC Server

Tabel 3. Spesifikasi PC Server

$\begin{array}{ll}\text { OS } & \text { Windows 10 } \\ \text { Processor } & \text { AMD FX-7500 up to 3.3 Ghz } \\ \text { Graphics } & \text { AMD Radeon R7 2GB } \\ \text { Memory } & \text { 8GB RAM } \\ \text { Storage } & \text { 500GB }\end{array}$

4. PC Client

Tabel 4. Spesifikasi PC Client

\begin{tabular}{|l|l|}
\hline OS & Windows 7 \\
\hline Processor & AMD E-450 1.65Ghz \\
\hline Graphics & 356MB \\
\hline Memory & 2GB RAM \\
\hline Storage & 300GB
\end{tabular}

\subsection{Skenario Pengukuran}

Skenario pengukuran dalam penelitian menjelaskan kinerja cloud gaming di sisi server maupun client. Aspek yang akan diuji yaitu Average CPU Usage. Untuk pengujian di sisi server maupun client dilakukan tiga skenario pengukuran yaitu:

1. Skenario A, pengukuran dilakukan pada sisi server dengan menjalankan dua judul game dengan tingkat resource usage yang berbeda, yaitu NEVERBALL dan 7 Days to Die secara bergantian dengan resolusi layar yang bervariasi dalam kondisi server GamingAnywhere tidak aktif dan aktif tanpa ada client yang terhubung.

2. Skenario B, pengukuran dilakukan pada sisi server dan client dalam keadaan satu client terhubung dengan server. Game NEVERBALL dan 7 Days to Die dimainkan secara bergantian dengan resolusi layar yang bervariasi

3. Skenario $\mathrm{C}$, pengukuran dilakukan pada sisi server dan client dalam keadaan dua client terhubung dengan server. Game NEVERBALL dan 7 Days to Die dimainkan secara bergantian dengan resolusi layar yang bervariasi. Client A menggunakan laptop physical dan client B menggunakan virtual machine. Client A bertindak sebagai pemain utama dan client B bertindak sebagai observer tetapi masih dapat melakukan control input. Untuk setiap skenario masing-masing dilakukan lima kali percobaan selama 2 menit dengan resolusi layar yang berbeda-beda yaitu 800 x 600, 1024 x 768, dan $1280 \times 720$. 


\section{Pembahasan}

Setelah melakukan pengukuran berdasarkan skenario yang telah dijelaskan pada 3.2 didapat hasil pengukuran sebagai berikut:

\subsection{Analisis Hasil Pengukuran Skenario A GamingAnywhere (GA) Non aktif dan Aktif tanpa client \\ Hasil pengukuran resource usage pada game} NEVERBALL dan 7 Days to Die dengan kondisi server GamingAnywhere (GA) tidak aktif dan aktif tanpa ada client yang terhubung (idle) terlihat pada gambar 8 . Hasil pengukuran merupakan rata-rata dari data yang telah dilakukan sebanyak 5 kali percobaan untuk setiap resolusi dengan waktu 2 menit.

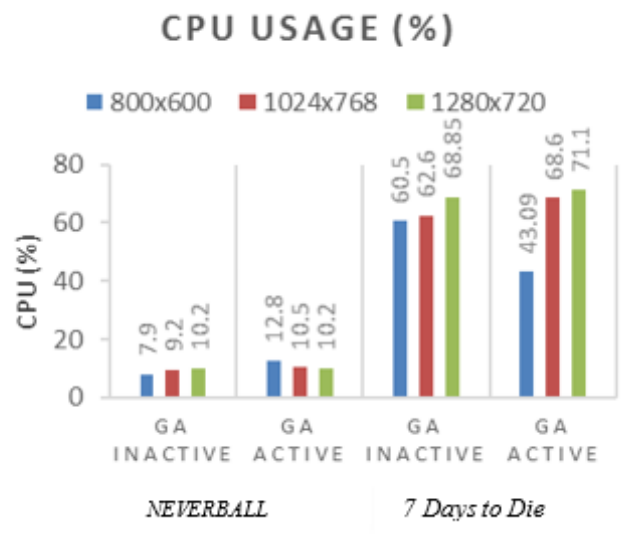

\section{Gambar 8. CPU usage pada server ketika GA non-aktif dan aktif}

Pada Gambar 8 di atas, menunjukkan bahwa CPU usage kedua game untuk setiap resolusi ketika server GamingAnywhere aktif sedikit lebih tinggi daripada ketika server tidak aktif. Pada server dengan game NEVERBALL, CPU usage meningkat sebesar $1.3 \%$ sampai dengan $4.9 \%$ dan pada game 7 Days to Die, CPU usage meningkat sebesar $2.25 \%$ sampai dengan $6 \%$. Hal ini disebabkan oleh GamingAnywhere yang melakukan proses instalasi ga-hook.dll pada game yang dijalankan.

Perbedaan CPU usage terjadi juga ketika memainkan game dengan resolusi berbeda. Semakin besar resolusi yang digunakan maka diperoleh nilai CPU usage yang besar. Hal tersebut dikarenakan semakin tinggi resolusi yang dipakai, maka pixel yang diproses lebih banyak dan rendering menjadi lebih berat.

\subsection{Hasil Pengukuran Skenario B dan C GA Aktif Tersambung satu client dan dua client}

Gambar 9 menunjukkan kondisi server dengan game NEVERBALL yang diakses oleh satu client sehingga, CPU usage tidak terlalu meningkat. Akan tetapi ketika diakses oleh dua client, terdapat peningkatan pada CPU usage sebesar $\pm 40 \%$. Peningkatan terjadi disebabkan oleh server yang harus mengenkode frame audio/video dan mengirimkan frame tersebut ke client secara realtime. Sistem GamingAnywhere yang menggunakan one-encoder-each-client, yang menyebabkan proses encoding video dan audio frames secara terpisah (dedicated) untuk masing-masing client sehingga load CPU yang bertambah.

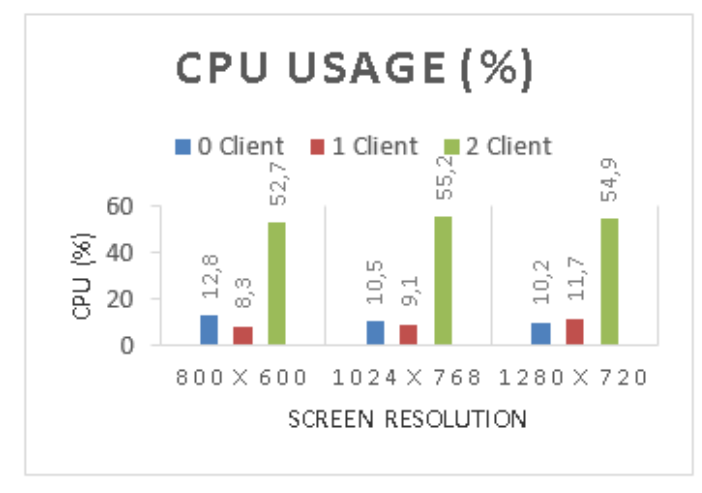

\section{Gambar 9. CPU usage pada server menggunakan game NEVERBALL ketika diakses beberapa client}

Kondisi server ketika diakses oleh dua client saat game 7 Days to Die dimainkan terlihat pada Gambar 10, resource usage rata-rata mengalami peningkatan. Peningkatan CPU usage yang dialami sebesar 19\% pada resolusi $800 \times 600 \mathrm{px}$, tetapi pada resolusi $1024 \times 768 \mathrm{px}$ dan $1280 \times 720$ px peningkatan yang terjadi tidak terlalu besar.

Peningkatan yang tidak terlalu besar pada CPU usage disebabkan oleh system requirement yang sangat besar hanya untuk menjalankan game 7 Days to Die dan Gaminganywhere hanya membutuhkan sedikit resource dalam menjalankan prosesnya sehingga peningkatannya tidak terlalu terlihat.

\subsection{Analisis Hasil Pengukuran dan Perbandingan Resource Usage pada Client dan Server \\ Berdasarkan Gambar 11 dan 12 menunjukkan} bahwa penggunaan CPU pada laptop client dengan game NEVERBALL bernilai $17.6 \%$ lebih rendah daripada server, dan dengan game 7 Days to Die CPU usage bernilai $46.7 \%$ lebih rendah dibandingkan dengan server. Hal ini disebabkan oleh client hanya menerima stream audio/video dan mengirimkan input control, sehingga load CPU akan kecil. Tetapi pada client yang menggunakan Virtual Machine (VM), terlihat CPU usage $20 \%$ lebih tinggi dari client pada laptop maupun server. Hal ini dikarenakan oleh jumlah thread CPU pada VM yang sangat terbatas dan terbagi oleh perangkat host-nya. 


\section{CPU USAGE (\%) \\ $\square 0$ Client $\square 1$ Client $\square 2$ Client

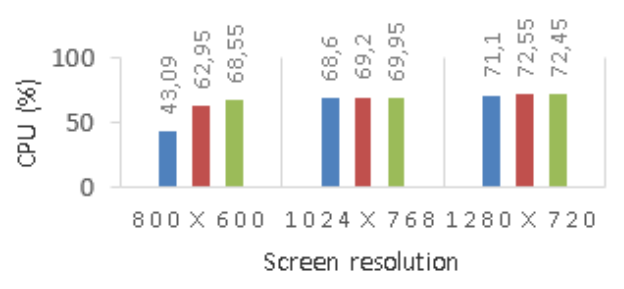

Gambar 10. CPU usage pada server menggunakan game 7 Days to Die ketika diakses beberapa client

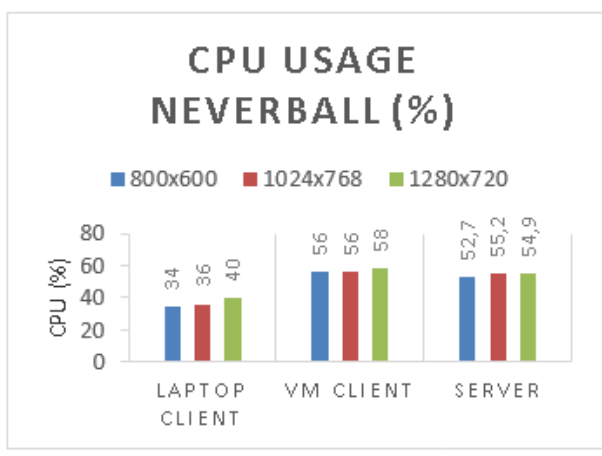

Gambar 11. Perbandingan CPU usage perangkat server dan client pada game NEVERBALL

\section{Kesimpulan dan Saran}

\subsection{Kesimpulan}

Sistem cloud gaming menggunakan platform GamingAnywhere mampu mengurangi beban resource usage CPU di sisi client, dimana client hanya menggunakan CPU usage sekitar 22-40\% untuk memainkan kedua game uji NEVERBALL dan 7 Days to Die.

Jumlah client yang terkoneksi dengan server mempengaruhi kinerja server karena platform GamingAnywhere menggunakan mode one-encoder-each-client, sehingga proses enkode terjadi dua kali untuk mengirimkan frame audio dan video ke masing-masing client.

\subsection{Saran}

Untuk penelitian selanjutnya disarankan untuk meneliti resource usage lainnya seperti RAM Usage dan Frame Rate Per Second (FPS).

\section{Daftar Pustaka}

[1] C.-Y. Huang, C.-H. Hsu, Y.-C. Chang, and K.-T. Chen, "Gaminganywhere: an open cloud gaming

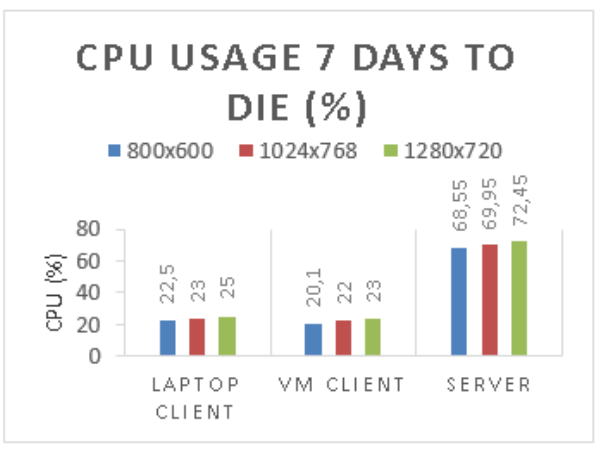

\section{Gambar 12. Perbandingan CPU usage perangkat server dan client pada game 7 Days to Die}

system," in Proceedings of the 4th ACM multimedia systems conference. ACM, 2013, pp. 36-47.

[2] C.-Y. Huang, K.-T. Chen, D.-Y. Chen, H.-J. Hsu, and C.-H. Hsu, "Gaminganywhere: The first open source cloud gaming system," ACM Transactions on Multimedia Computing, Communications, and Applications (TOMM), vol. 10, no. 1s, p. 10, 2014.

[3] R. Munadi, N. Fitriyanti, I. P. P. Sutejo et al., "The quality of services (qos) of gaminganywhere on a game with speech recognition system as command input," Jurnal Elektro dan Telekomunikasi Terapan, vol. 5, no. 2, pp. 682-692, 2018.

[4] S. Harada, J. O. Wobbrock, and J. A. Landay, "Voice games: investigation into the use of non-speech voice input for making computer games more accessible," in IFIP Conference on Human-Computer Interaction. Springer, 2011, pp. 11-29.

[5] A. Ashari and H. Setiawan, "Cloud computing : Solusi ict ? indonesia," Sistem Informasi (JSI), vol. 3, no. $2,1983$.

[6] C.-Y. Huang, D.-Y. Chen, C.-H. Hsu, and K.-T. Chen, "Gaminganywhere: an open-source cloud gaming testbed," in Proceedings of the 21st ACM international conference on Multimedia. ACM, 2013, pp. 827-830.

[7] B. Plannerer, "An introduction to speech recognition," Munich, Germany, 2005.

[8] "best virtual machine applicatios," http://blog.legacyteam.info/2014/11/ best-virtual-machine-applications/, 2014.

[9] “"what is a game server ?" https://www.eukhost.com/ blog/webhosting/what-is-a-game-server/, 2009. 